\title{
Synthesis and Conclusion
}

This study has provided the first detailed analysis of a particular āsipu's education and practice. A number of surprising features have been illuminated through the analysis of Kișir-Aššur's education, which indicates that it was different from what we would expect. Kișir-Aššur copied prescriptions related to the treatment of snakebites, scorpion stings and horses as šamallu șehru. All three areas of healing consist of prescriptions and they are usually regarded as uncommon in Mesopotamian healing. The study showed that these areas of healing likely provided Kișir-Aššur with a conceptual framework for interpreting the overwhelming powers of venomous liquids, which could be used for understanding the physiological processes of the human body. The venoms were generally compared to the bile found in mammals, which may have provided an explanatory physiological framework. In relation to the veterinarian prescriptions, it is possible that Kiṣir-Aššur used knowledge about animal anatomy to gain an understanding of the internal mechanisms of the human body. Additionally, it was proposed that he could have practiced horse treatments and it may be possible to extrapolate from this that Kișir-Aššur also acted as a veterinarian. Kiṣir-Aššur also copied several medical manuscripts with diagnoses, symptom descriptions, and treatments of various illnesses. These therapeutic texts appear to have been copied according to assignments focusing on an anatomical or physiological area of the body, according to a specific ailment, or handpicked sections from a collection of prescriptions. Concerning his diagnostic capabilities, Kișir-Aššur may have been trained in diagnostics through a combination of the therapeutic texts from his šamallu șehru-phase and oral teachings. Significantly, according to the surviving evidence he never copied Sa-gig, which is assumed to have been the primary tool with which to learn diagnostic principles. The numbered extracts that he produced as šamallû șehru may have provided him with the most useful text passages for acquiring all the abovementioned skills. Additionally, Kișir-Aššur was trained in methods for treating causes of illness by petitioning or influencing the responsible deity through prayer, ritual actions, and substitution. Surprisingly, he also seems to have taught basic scribal skills to at least one younger pupil.

After his šamallû șehru-phase, Kișir-Aššur copied rituals for removing the affliction "Curse" and gaining an overview of the confinement ritual bìt mēseri. As šamallû mašmaššu șehru, he copied texts intended to soothe ghosts or personal gods in a domestic setting. During this phase, he also copied a text for 
prophylactically calming a baby or child. It is possible that the texts he copied provided a continuous focus on knowledge related to understanding and learning how to practice healing. I presented evidence to suggest that KișirAššur may himself have acted as a paediatrician during this phase. Although child calming rituals are known to have been part of the ǎšipu's proficiencies, it is interesting that it appears at this point in his training, after a period in which he studied texts related first primarily to medicine and afterwards aimed at performing and understanding more advanced rituals. During the mašmaššu šamallû șehru-phase he also copied texts for treating possible domestic causes of misfortune. This process, I suggested was intended to widen the young āšipu's scope from individual, to house, to cult, to family, and following the mašmaššu șehru-phase, to entire households. Kișir-Aššur, while probably trained under his father's supervision, may therefore have experienced increased autonomy in certain areas of practice during some phases. It is possible that he treated animals as šamallû șehru and later infants, babies, or children as šamallû mašmaššu șehru, with increased autonomy in order to gain more experience. Additionally, it is also possible that this sequence of medical training was the result of an intrinsic ethical and economic system, which allowed greater room for medical errors on animals and to some extent on young children. This suggestion is based on the observation that animals could be replaced through economic compensation, whereas the failed treatment of an infant, baby, or child could perhaps damage the healer's social reputation. It is therefore possible that medical incompetence in relation to adult healing was the only form of negligence that could potentially terminate a healer's practice.

The mašmaššu șehru-phase was the first time since the šamallû șehru-phase that he copied prescriptions (bultu). Furthermore, these were described as "tested" procedures. When Kișir-Aššur became mašmaššu, he surprisingly does not seem to have been fully trained. It is likely that he was not allowed to supervise rituals and perform house calls on his own until sometime during this phase. Yet, the material attests to an increase in authority, as he copied rituals designed for conducting house calls and rituals for protecting entire households during this phase. He had previously acquired insight into such rituals as šamallû. Furthermore, the fact that purpose statements and namburbirituals generally do not appear before this phase indicates that these were elements connected with supervising rituals and conducting house calls without supervision.

A significant result of this monograph relates to practical, as opposed to abstract, theoretical knowledge. Many of Kișir-Aššur's tablets appear to be extracts in some form. Some tablets were numbered according to obscure principles, possibly numbering excerpts extracted from larger texts, whereas 
other manuscripts were simply mined for Kișir-Ǎšur's practice. What is clear, however, is that Kișir-Aššur's texts often seem to have been copied and extracted for specific purposes, such as training and practice. They therefore reflect practiced knowledge. Kișir-Aššur's use of tested prescription, and perhaps his own test of at least one prescription, during his mašmaš bìt Ǎ̌šur-phase, coupled with many purpose statements on medical and ritual tablets from the mašmaššu- and mašmaš bit Aššur-phases, as well as on tablets without titles, attest to the practical implementation of this knowledge. It appears that as mašmaš bìt Ǎšsur he may have depended on fewer but more trustworthy prescriptions, of which at least one prescription was universally applicable. Furthermore, the evidence suggests that rituals connected to witchcraft and hostility were related to Kiṣir-Aššur's later career phases.

Overall, Kișir-Aššur's medical texts may be assigned to three major groups relating to: internal, renal, and rectal illnesses; illnesses affecting the "strings", the motoric system, and the lower extremities; and a limited number of complex illnesses or causes of illness. In particular, the group concerning internal, renal, and rectal illnesses seems to be part of Kișir-Aššur's practice. Whether or not these areas reflect his personal specialization(s), or whether he even had an area of specialization, remains uncertain. Furthermore, if the majority of his texts had a practical dimension, it is probable that the texts from his mašmaš bit Aššur-phase related to the Aššur temple were practical tools used in connection to specific duties, to familiarize Kiṣir-Aššur with the cult of Aššur, or as models that were modified according to need.

From a microhistorical point of view, this study provides a foundation for further in depth analyses of individual healers' training and practice. Surprisingly, Kișir-Aššur rarely produced exact copies with colophons of the established series, and some texts are only known from his manuscripts or from duplicates in the $\mathrm{N}_{4}$ collection. Although this is not necessarily proof of an idiosyncratic scholarly environment in $\mathrm{N}_{4}$, it does indicate that the texts Kișir-Aššur copied and used occasionally fell outside the parameters we know from the royal collections in Nineveh. It is possible that his texts reflect textual traditions specific to the scholarly environments of the city of Assur. However, Kișir-Aššur's copies of texts from these traditions indicate that they were part of his training and practice. Kișir-Aššur does not appear to have been trained according to current interpretations of the Exorcist's Manual, although the limited number of scholarly texts from around his mašmaššu-phase may reflect the wider range of advanced scholarship that was encouraged in the second part of the EM. Thus, the evidence presented cautiously speaks in favour of abandoning the EM as a verbatim curriculum for becoming an āšipu. The inclusion in KiṣirAššur's training and practice of texts of other and different types of medical 
knowledge than are explicitly listed in the EM may indicate that the professional profile of the exorcist had undergone changes since the time the EM was composed. However, this question requires further analysis, ideally combined with a discussion of the development of the āšipu profession in later periods.

By investigating the small mysteries of medical practice that individual manuscripts presented, this study has examined the wider use of veterinarian and paediatric knowledge in Mesopotamia. Furthermore, physiology has rarely been discussed in relation to whether or not a Mesopotamian conception of internal underlying processes existed. Building on previous research, I hypothesized that a system concerning fluids, such as venom and bile, may have been used in metaphoric relationships to establish a conception of how some aspects of the internal parts of the body functioned.

Therefore, by considering all of a single āšipu's texts from his entire career, it is possible to achieve a more diverse understanding of the purposes that individual texts may have served, independent of genre labels. This monograph has provided a well-rounded and holistic analysis that emphasises emic perspectives with the added etic background where necessary. The publication of further tablets will potentially modify these results, yet such modifications will not significantly change the conclusions drawn concerning Kișir-Aššur as a case study of a practitioner working at a specific time, in a certain location. This study has striven towards not overemphasizing particular individual features, as well as accounting for the amount of unattainable knowledge, such as oral teachings. However, both the fragmentary material and the method have their limits and many of the results remain, unavoidably, hypothetical. Therefore, this study does not hold all the answers regarding Kișir-Aššur's magico-medical focuses or the impact they had on his career. Further research into the orthography and spelling habits of Kișir-Ǎšsur and his family may enable additional $\mathrm{N}_{4}$ texts to be assigned to specific members of the Bāba-šumaibni family. However, a comprehensive examination of such features is beyond the scope of the present analysis. Nonetheless, comparative texts and general theories have provided the necessary background and supporting information, in accordance with the microhistoric approach, to support my observations about Kișir-Aššur.

In a broader perspective, a number of preliminary observations regarding the similarities and differences between Kișir-Aššur and contemporary āšipus at the royal court might highlight possible areas for future studies. A few exorcists at the royal court in Nineveh may have overseen the treatment of children in addition to adults (see Section 5.2.2). The arguments presented here, regarding Kișir-Aššur's hypothesized practice as a paediatrician, indicate that such duties may have been part of some exorcists' professional obligations. 
However, we currently know little about the concrete development in patient groups or changing responsibilities of other individual healers. The letters and reports from Nineveh suggest that court āšipus never quoted Sa-gig, and at least one exorcist tested a prescription before use on patients (see Sections 3.6.1 and 8.3.1). Therefore, current research tentatively implies that some āšipus at court depended on, e.g., experience in their practice. Kișir-Aššur did not copy Sa-gig, as far as we know. Furthermore, Kișir-Aššur also depended on experience to some degree, as well as pragmatism, which is evidenced by his use of fewer trusted prescriptions in later phases and the proposed test of a prescription during his mašmaš büt Aššur-phase. Yet, other aspects of Kișir-Aššur's practice perhaps contrast that of exorcists in Nineveh. While rituals at court could be copied in their entirety for what may have been strict performances (see Section 7.4), Kișir-Aššur's manuscripts demonstrate how relevant sections of both medical and ritual texts were chosen and copied for concrete purposes. Some such texts likely served as aide mémoires, and rituals were perhaps adapted according to specific circumstances.

While Kișir-Aššur and his family perhaps had occasional professional contact with the Assyrian kings, little evidence suggests he had direct access to the Nineveh court and its scholarly knowledge. Like one exorcist at court, KișirAššur perhaps had private clients as mašmaš bit Aššur in addition to his possible duties at the Aššur temple (see Section 8.7). Unlike the letters and reports from the Nineveh exorcists, Kișir-Aššur's manuscripts provide us with scholarly texts copied for specific professional purposes, and they show how he operated within a local and distinctive scholarly environment. Thus, Kișir-Aššur primarily acquired texts via the local learned community and its institutions. Although Kiṣir-Aššur was not part of the inner circle of scholars at Nineveh, certain aspects of how he practiced his profession seem to be roughly similar to some of the routines of the āsipus at the royal court. Yet, other aspects of his practice do not appear to be comparable. It remains possible, however, that the conclusions drawn regarding Kișir-Aššur's training and career are not generally applicable to wider medical practices in Mesopotamia, and perhaps not even in the NA period. These questions require further research, and they will hopefully be addressed in the future. Yet, this study has shown that Kiṣir-Aššur's texts reveal a localized tradition of medical knowledge.

By focusing on practical rather than abstract knowledge, the case of KișirAššur provides a contextualized and comprehensive study of how medical knowledge in all forms was used by a specific ancient healer. Consequently, this work not only adds to our knowledge of how ancient texts were used, but differs significantly from some contributions on Mesopotamian medicine. It is therefore my hope that it serves as a step towards gaining a deeper understanding of medical practices in ancient Mesopotamia. 